\title{
Sensory Profiling and Hedonic Evaluation of Attiéké from Local and Improved Cassava Varieties
}

\author{
Justine Bomo Assanvo'1*, Georges N'zi Agbo'1, Judith Brunnschweiler Beez², Vincent Monsan ${ }^{3}$, \\ Zakaria Farah ${ }^{2}$
}

${ }^{1}$ UFR Biosciences/Laboratory of Biochemistry and Food Science, University Félix Houphouët-Boigny, Abidjan, Côte d'Ivoire ${ }^{2}$ Institute of Food Science and Nutrition/Laboratory of Food Chemistry and Technology, Swiss Federal Institute of Technology (ETH), Zurich, Switzerland

${ }^{3}$ UFR Mathematics and Computer Science, University Félix Houphouët Boigny, Abidjan, Côte d'Ivoire

Email: *justinebomo2015@gmail.com

How to cite this paper: Assanvo, J.B., N'zi Agbo, G., Beez, J.B., Monsan, V. and Farah, Z. (2018) Sensory Profiling and Hedonic Evaluation of Attiéké from Local and Improved Cassava Varieties. Food and Nutrition Sciences, 9, 1472-1497.

https://doi.org/10.4236/fns.2018.912107

Received: November 5, 2018

Accepted: December 26, 2018

Published: December 29, 2018

Copyright () 2018 by authors and Scientific Research Publishing Inc. This work is licensed under the Creative Commons Attribution International License (CC BY 4.0).

http://creativecommons.org/licenses/by/4.0/

\begin{abstract}
Attiéké is fermented cassava semolina steamed and consumed with proteins and vegetables. From Ivorian traditional origin, its popularity is increasing in Africa and production networks are developing. However, the growth of attiéké industry is still curbed by lack of technical skills of producers and irregular quality, depending on cassava variety, processing and inoculum. In the present study, a traditional inoculum and four cassava varieties (two improved local (IAC and Bonoua) and two improved sweet ones from Nigeria (Olekanga and TMS 4 (2) 1425)) were used for producing attiéké Ebrié. For the sensorial evaluation of prepared attiéké, qualitative sensory profiling was used. The sensory quality descriptors where quantitatively measured by a trained sensory panel. With this method the most important quality criteria of attiéké were judged. These quality criteria were selected with the aid of surveys on its production and consumption. The relationships between sensory attributes of the four attiéké prepared of the different cassava varieties and biochemical characteristics were studied. Sensory analysis revealed that the four attiéké were cream-colored products with sweet and/or sour tastes, made of cohesive and well-formed grains of different sizes, with an odor of fermentation specific to attiéké and showing a firm texture. The differences between sensory profiles of the four attiéké produced from four cassava varieties (12 months growth) concern only some descriptors of quality. Pearson correlation coefficients between physicochemical descriptors of quality showed that biochemical parameters may help predict organoleptic characteristics of attiéké Ebrié ( $\mathrm{pH}$-size of grains: $\mathrm{r}=0.99$; $\mathrm{pH}$-acidity: $\mathrm{r}=-0.92$; acid-
\end{abstract}


ity-rounded grains: $\mathrm{r}=-0.98$ : starch-cohesion between grains: $\mathrm{r}=-0.96$; starch-sweet: $r=-0.95$; starch-granulous: $r=0.97$, total sugar-yellow color: $r=$ 0.96 ; total sugar-aroma of attiéké: $r=0.96$; reducing sugar-odor of attiéké: $r=$ 0.95 ; cyanide-fibrous: $r=0.95$ ).

\section{Keywords}

Cassava, Attiéké, Sensory Profile, Hedonic Quality, Physicochemical Characteristics

\section{Introduction}

Attiéké is fermented cassava semolina steamed and consumed with proteins and vegetables. Attiéké was originally consumed exclusively in a restricted ethno-cultural setting in the lagoon complex of Côte d'Ivoire where ethnic groups as Adjoukrou, Ebrié, Alladjan, Avikam, Aizi and Néo lived. Adjoukrou, Ebrié and Alladjan remain the biggest producers and consumers of attiéké [1].

Nowadays, attiéké has overflowed its original environment and is consumed throughout the country because of its "ready-to-eat" presentation [2]. The consumption of attiéké in Côte d'Ivoire is now estimated around 1,300,000 tons/year based on extrapolation of quantities consumed (34,000 tons/year) in 1983 [3] and demographic growth.

The popularity of this food has grown very much in Africa in the last decade and networks of production systems are developing. Also other foods similar to attiéké have been investigated [2] [4]. However, the development of an attiéké industry is still handicapped by non-mastery of production techniques and irregularity of product quality influenced by cassava variety, processing and inoculum. Moreover, in some cases, the bad control of preparation conditions may influence its organoleptic quality, especially in terms of texture and taste [4] [5].

The methods of manufacturing attiéké are multiple and vary among ethnic group. Once cooked, attiéké may be preserved up to one week depending on the region [1]. The lack of control of several factors (cassava varieties, inoculum, temperatures, time and preparation conditions) constitutes most of the constraints leading to manufacturing defaults and low yields [6].

Several varieties of cassava are used for producing many fermented meals, but bitter cassava (containing toxic substances as cyanides) has a better technological aptitude for transformation (yield, organoleptic quality etc.) than sweet cassava varieties [7]. The transformation process aims at eliminating the bitter substances of cassava and shaping of small round grains having the capacity to absorb large quantities of water [8].

After cooking, attiéké may have free grains of yellowish color and translucent appearance [9]. For traditional producers, attiéké is characterized by well-rounded, well-formed grains, brilliant color (yellow, cream, cream-yellow and white-brown), slightly acid or neutral taste, typical smell and a pleasant 
slight aroma of fermentation. The absence of fibers and the more or less sticky, elastic, pasty and dry character of attiéké determine the choice of consumers [4].

Attiéké has been analyzed at production, economic, physicochemical and microbiological levels [2] [5] [10] [11] [12] [13].

For attiéké, most sensory studies concentrated on hedonic evaluation [4] [14] [15] [16]. However, in the present study the more objective quantitative sensory profiling method has been used because of limited data on the organoleptic characterization of attieké.

This present work is part of research for the improvement of the quality of Ivorian traditional attiéké. The physicochemical and microbiological characteristics of attiéké ebrié prepared from four varieties of cassava have already been reported [17]. The present study concentrates on sensory analysis of this product. Furthermore cassava varieties that can be transformed into reproducible attiéké of desired organoleptic quality were determined.

For the sensory evaluation of attiéké quality criteria considered as important were identified and quantified by sensory analysis. The biochemical parameters were used as indicators of sensory properties identified.

\section{Material and Methods}

\subsection{Plant Material}

Sensory and hedonic measurements were performed on attiéké Ebrié prepared from four cassava varieties, including two improved local (Bonoua and IAC) and two improved ones from Nigeria (TMS 4 (2) 1425) and Olekanga (also known as TME 9) that were harvested at 12 months of age in a farm near the village of Bringakro in Central Côte d'Ivoire (about $440 \mathrm{~km}$ from Abidjan), (Table 1). The variety IAC served as a control for the various treatments performed. Attiéké was processed from Cassava, two days post-harvest.

\subsection{Technological Treatment of Attiéké}

The studied attiéké were prepared according to the manufacturing process

Table 1. Presentation of the four varieties of cassava roots harvested at Bringakro (Toumodi).

\begin{tabular}{cccccc}
\hline Variety & Type & Origin & $\begin{array}{c}\text { Mean Yield } \\
\text { (t/ha) at } 11 \\
\text { month }\end{array}$ & $\begin{array}{c}\text { Dry matter } \\
\text { content (\%) }\end{array}$ & Preparation \\
\hline IAC & $\begin{array}{c}\text { Local, control } \\
\text { variety }\end{array}$ & Cote d'Ivoire & 27 & 35.3 & Attiéké \\
$\begin{array}{c}\text { Olékanga } \\
\text { (TME 9) }\end{array}$ & Improved & IITA, Nigeria & 22 & 30.5 & Multiple \\
Bonoua & Local & Cote d'Ivoire & 9 & 34.7 & Multiple \\
TMS4(2)1425 & Improved & IITA, Nigeria & 25 & 32.5 & Multiple \\
\hline
\end{tabular}

Multiple: transformation of cassava into attiéké, pulp, foutou; IITA = International Institute of Tropical Agriculture; IAC = Improved African Cassava. 
described as in [17]. Two traditional Ebrié producers from Adiopodoumé village applying a similar process in attiéké production were selected based on a consumption survey. Briefly, the paste obtained from grinded cassava roots was mixed with traditional inoculum (10\%) and discolored red palm oil (0.1\%). After 15 hours of fermentation at room temperature $\left(28^{\circ} \mathrm{C}-32^{\circ} \mathrm{C}\right)$, the mixture was pressed and sieved $(0.5 \mathrm{~cm})$. The cleaned semolina was sun dried $\left(25^{\circ} \mathrm{C}-40^{\circ} \mathrm{C}\right)$ and steamed $\left(100^{\circ} \mathrm{C} / 30 \mathrm{~min}\right)$ to obtain attiéké (Figure 1).

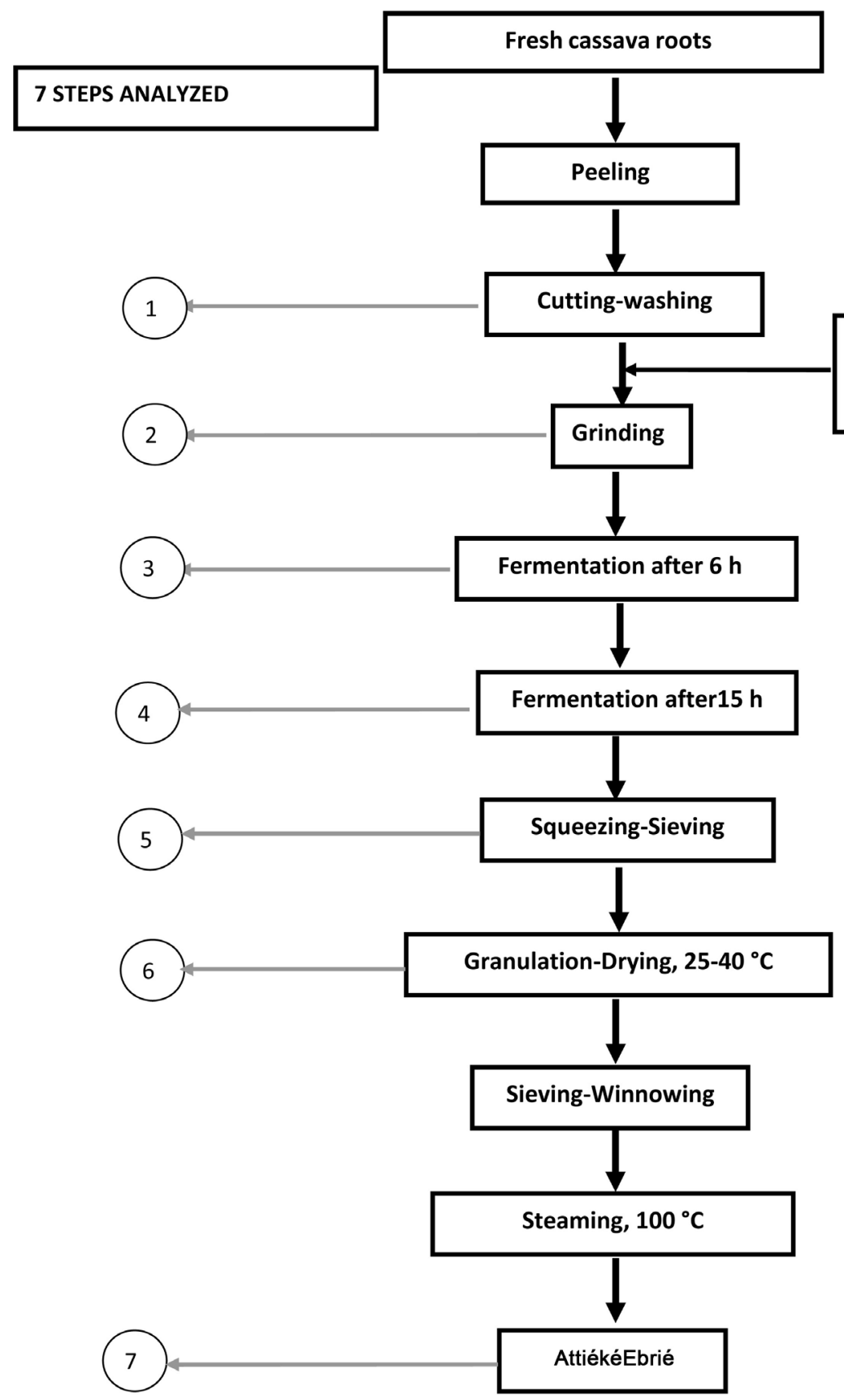

Figure 1. Diagram presenting the 7 steps of manufacturing process of traditional attiéké Ebrié and cassava inoculum analyzed. The different numbers correspond to the 7 steps of samplings. Some steps of the manufacturing process were gathered for highlighting the 7 analyzed steps. 
For the investigation, each producer prepared the traditional inoculum from only one cassava variety. Attiéké from the four varieties was prepared simultaneously by the two processors.

\subsection{Sampling for Biochemical Analysis}

Biochemicals included $\mathrm{pH}$, acidity, rates of starch, total and reducing sugars, cyanide were studied for the finished product, attiéké. For analyses, 12 samples (3 samples/variety) were collected for 3 sessions (3 repetitions), [17].

\subsection{Sampling for Sensorial and Hedonic Analysis}

The sampling was performed during three successive sessions of degustation. For sensory analysis, 13 panelists were selected and each person received randomly and consecutively the four attiéké studied during each session that lasted two days (time of attiéké production). A total of 52 samples were distributed per session corresponding to 156 samples for the three tasting sessions.

For hedonic analyses, 78 native tasters received randomly and consecutively the four attiéké studied, during each session. A total of 936 samples were tested during three tasting sessions.

\subsection{Biochemical Analysis}

For each fresh sample, the $\mathrm{pH}$ and total titrable acidity were determined. These samples were lyophilized (lyophilisator Christ Alpha 1-2, Gefriertrocknungsanlagen GMBH, Germany-Osterode am Harz), then reduced (crusher MFC, IKA ${ }^{\circ}$ LABORTECH, Janke \& Kunkel GMBH and CO. KG., Germany-Staufen) in flour for analyzing the remain biochemicals.

The $\mathrm{pH}$ of $10 \mathrm{~g}$ of each sample suspension ( $90 \mathrm{ml}$ of distilled water), was measured using a pH meter (Calimatic 761, Knick). Then $100 \mathrm{ml}$ of distilled water were added to the mixture and homogenized under magnetic stirring. After addition of 8 drops of phenolphthalein $2 \%$, the solution was titrated with $0.1 \mathrm{M}$ $\mathrm{NaOH}[18]$.

The starch content in $0.1 \mathrm{ml}$ of filtered solution obtained from flour $(100 \mathrm{mg})$ of attiéké, treated with ethanol $40 \%$, was determined by enzymatic way after hydrolysis by amyloglucosidase (enzymatic Kit of Boehringer Mannheim R. Biopharm GMBH, Darmstadt, Germany, 1997). The absorbance was measured at $340 \mathrm{~nm}$ with a spectrophotometer (WTW photolab S12). The assays were repeated three times for each sample.

For the study of reducing and total sugars [19]), $1 \mathrm{~g}$ of each sample of attiéké was treated with ethanol $(80 \% \mathrm{v} / \mathrm{v})$ and defecated in the presence of lead acetate solution $(10 \% \mathrm{v} / \mathrm{v})$ and oxalic acid $(10 \% \mathrm{v} / \mathrm{v})$.

The study of hydrocyanic acid was carried out on $100 \mathrm{mg}$ of fresh attiéké flour using the method of picrate [20].

Physicochemical characteristics of the four prepared attiéké are listed in Table $2[17]$. 
Table 2. Means \pm standard deviations of physicochemical characteristics of attiéké.

\begin{tabular}{|c|c|c|c|c|c|c|c|c|}
\hline \multirow[b]{2}{*}{$\begin{array}{c}\text { Cassava } \\
\text { varieties }\end{array}$} & \multicolumn{8}{|c|}{ Physicochemical characteristics } \\
\hline & Type & $\begin{array}{c}\text { Stage of } \\
\text { manufacturing } \\
\text { process }\end{array}$ & $\begin{array}{c}\text { Starch } \\
(\mathrm{g} / 100 \mathrm{~g} \mathrm{dm})\end{array}$ & $\begin{array}{l}\text { Total sugar } \\
(\mathrm{g} / 100 \mathrm{~g} \mathrm{dm})\end{array}$ & $\begin{array}{c}\text { Reducing } \\
\text { sugar } \\
(\mathrm{g} / 100 \mathrm{gdm})\end{array}$ & $\begin{array}{c}\text { Cyanide } \\
(\mathrm{mg} / \mathrm{kg} \mathrm{dm})\end{array}$ & $\mathrm{pH}$ & $\begin{array}{c}\text { Total titrable } \\
\text { acidity (\%) }\end{array}$ \\
\hline IAC & Local & Attiéké & $90.68 \pm 0.86$ & $1.19 \pm 0.07$ & $0.27 \pm 0.01$ & $4.83 \pm 0.08$ & $4.56 \pm 0.09$ & $0.60 \pm 0.07$ \\
\hline BONOUA & Local & Attiéké & $91.39 \pm 0.84$ & $0.94 \pm 0.08$ & $0.25 \pm 0.01$ & $2.79 \pm 0.15$ & $4.65 \pm 0.05$ & $0.53 \pm 0.04$ \\
\hline OLEKANGA & Improved & Attiéké & $80.21 \pm 1.79$ & $1.22 \pm 0.12$ & $0.28 \pm 0.01$ & $2.87 \pm 0.24$ & $4.58 \pm 0.13$ & $0.61 \pm 0.09$ \\
\hline TMS (2) 1425 & Improved & Attiéké & $86.70 \pm 1.35$ & $1.43 \pm 0.08$ & $0.29 \pm 0.02$ & $5.00 \pm 0.09$ & $4.62 \pm 0.13$ & $0.54 \pm 0.07$ \\
\hline
\end{tabular}

$\mathrm{N}=12$ samples.

\subsection{Sensory and Hedonic Analysis}

\subsubsection{Recruitment of Panelists}

Test conditions have been explained to the panelists. Thereafter panelists decided whether they wanted to participate at the degustation or not. The persons who decided to participate at the test sessions were at any time free to stop participation.

No approving ethics committee is necessary for the present research.

\subsubsection{Hedonic Test}

The four attiéké were presented to 78 native Ebrié tasters (70\% women and 30\% men aged from 24 - 50 years), monadically according to 9 levels of appreciation from extremely good to extremely bad. The hedonic tests were repeated three times on the four studied attiéké, in parallel to the three sessions (repetitions) of the quantitative sensory profiling.

\subsubsection{Sensory Profiling}

\section{1) Panel training}

Sensory analysis of attiéké from the four cassava varieties was carried out by a tasting panel trained for the quantitative sensory profiling similar to the Quantitative Descriptive Analysis [21] in an appropriate room at the Swiss Centre of Scientific Research (CSRS), Abidjan. A group of 13 panelists (3 women and 10 men, 22 - 45 years of age), including students, laboratory technicians and teachers were trained for tasting attiéké during 12 sessions. During seven-week sessions, panelists were trained and they learned to describe the quality attributes of attiéké and using an unstructured linear scale.

A scale was used for each descriptor and reference products for intensity levels were defined (Figure 2). These references were presented to the tasters for better describing the different quality attributes.

Each session of sensory analysis performed during the period of harvesting cassava roots (12 months of age) was preceded by a three-session recycling test.

\section{2) Quantitative sensory profiling}

A $100 \mathrm{~mm}$ unstructured linear scale (minimal intensity = Not at all; maximum intensity $=$ Strong) was used to measure the intensity of each descriptor. 


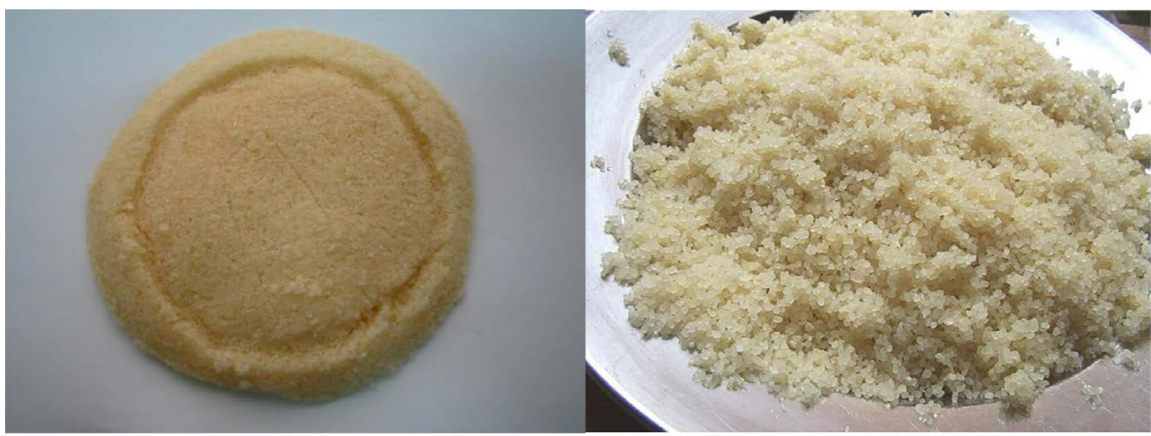

(a)

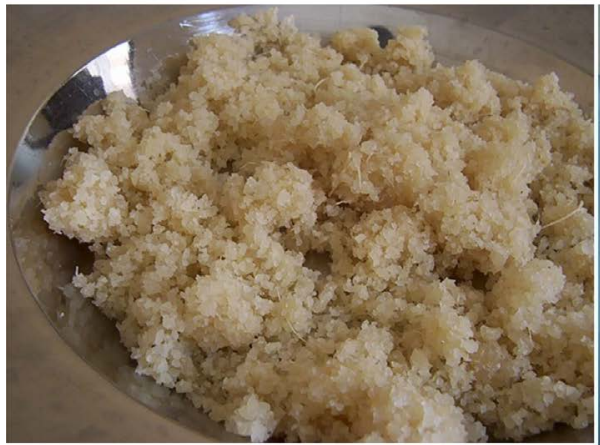

(c) (b)

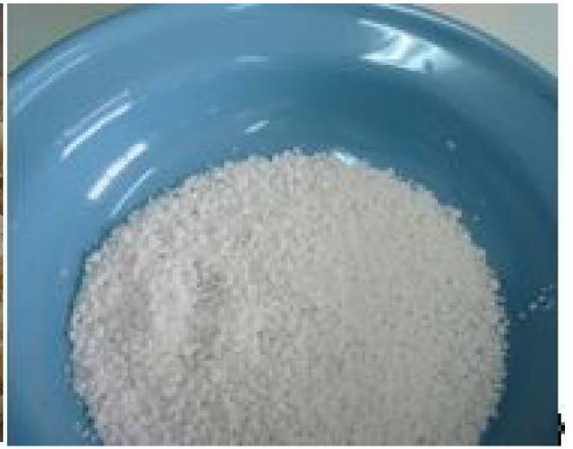

(d)

Figure 2. Some reference products for sensory attributes and a sensory evaluation session of attiéké (Cl. Assanvo J.B). (a): Attoupkou: a traditional fermented cassava bread cooked with steam; (b): Attiéké Agbodjama: a traditional fermented cassava semolina with large gains; (c): Attiéké Garba: a bad game quality of traditional semolina fermented cassava; (d): Tapioca: a traditional starch semolina cassava.

The taster was invited to mark the intensity of the sensation perceived for each descriptor with a vertical line. For a tasting session, tasters were divided into two groups. Three sessions corresponding to three sessions were conducted. Each session lasted for two days (duration of attiéké production). The samples were identified by three-digit codes on self-adhesive papers. In a coded hollow dish, $100-130 \mathrm{~g}$ of attiéké (temperature $=30^{\circ} \mathrm{C}$ ) was distributed monadically and randomly. The panelist were seated separately, one per table.

For the final tests, the proposed scale was linear and unstructured with no references to the extremities.

15 attributes describing organoleptic properties (appearance, odor, aroma, texture and savor) of attiéké were selected. At the level of optical appearance, the descriptors were yellow color, brightness, well-shaped grains, size of grains, round or angular grains, presence of fibers as well as moisture. Furthermore, the intensity and the presence of the characteristic odor of attiéké were evaluated. With the fingers (texture), elasticity of attiéké and cohesion between grains (glue effect) were tested. In the mouth firmness, aroma, granular structure, acid and sweetness were tested. The descriptors of attiéké quality were established compared to reference products.

A total of four attiéké from four selected varieties of cassava were tested (Figure 3 and Figure 4). The attiéké of variety IAC served as control. 


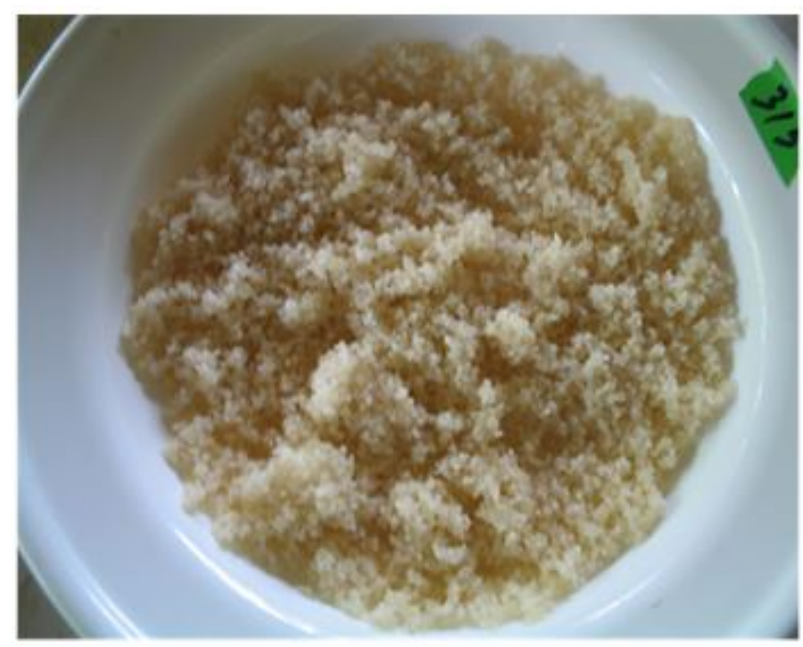

Figure 3. Presentation of attiéké Ebrié freshly cooked (Cl. Assanvo J. B.).

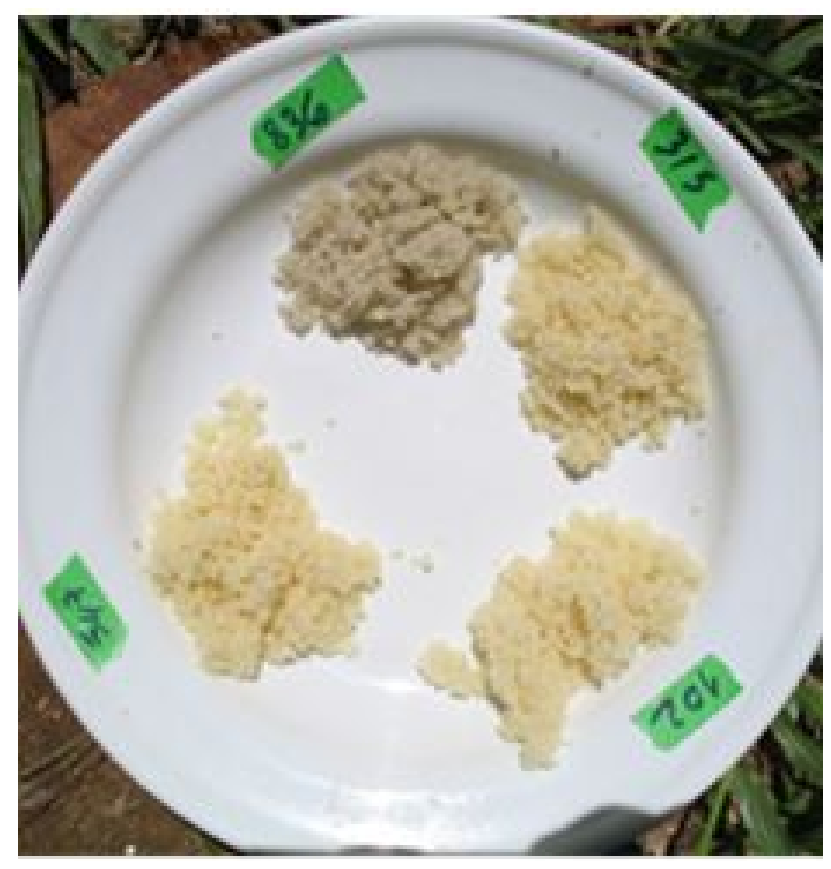

Figure 4. Presentation of 4 attiéké of 4 cassava varieties studied (Cl. Assanvo J. B.) Code 315 = attiéké of IAC variety; Code 836 = attiéké of Bonoua variety; Code 547 = attiéké of TMS 4(2)1425 variety; Code 102 = attiéké of Olekanga variety.

\subsection{Statistical Analysis}

Statistical analysis was performed using SAS software version 8.0.

A three-factor variance analysis model was used, the three factors being repetition (session corresponds to repetition), panelist (random effect) and attiéké product (attiéké was linked to variety).

The dependent variable responses were: hedonic character, yellow color, brightness (translucency), well-formed grains, grain size, rounded grains, pres- 
ence of fibers, moist, aroma, cohesion between grains, elastic character, firm character, granular structure, acid and sweet taste. The significant threshold is $\alpha=0.05$.

The statistical tests of hedonic analysis were carried out on data obtained from three repetitions of tasting. For these measured hedonic variables, the means were calculated. With pairwise comparison of averages, a classification of notes obtained during tasting was realized. For the quantitative sensory profiling, statistical analysis was carried out on data obtained from three repetitions of tasting. For measured variables, means were calculated and sensory profiles of the four attiéké were established.

Calculation of Pearson correlation coefficient was performed between different sensory attributes of attiéké and between different sensory attributes and biochemical parameters (Table 2) to determine the significant correlations.

A principal component analysis was made for varieties and quality descriptors of attiéké.

The mathematical model of three-factor analysis (with random effect) was as following

$$
Y_{i j k}=\mu+i+j+k+\varepsilon_{j k}+e_{i j k}
$$

with

$$
\begin{aligned}
& Y_{i j k}=\text { response variable, } \\
& \mu=\text { constant, } \\
& \alpha_{i}=\text { panelist effect which is random, } \\
& \beta_{j}=\text { product effect (fixed variable), } \\
& \gamma_{j}=\text { repetition effect (fixed variable), } \\
& \varepsilon_{j k}=\text { product interaction effect * repetition, } \\
& e_{i j k}=\text { residual errors, } \\
& \text { The significant threshold was } \alpha=0.05 .
\end{aligned}
$$

\section{Results}

\subsection{Hedonic Evaluation of Attiéké}

There was no panelist effect $(\mathrm{p}=0.3194)$, nor a repetition effect $(\mathrm{p}=0.1011)$. However, there was a product effect $(\mathrm{p}=0.0002)$ as well as repetitive and product interaction effects $(\mathrm{p}=0.0319)$ on hedonic characters. Attiéké of variety IAC (control) had the highest score (7.00) meaning a good level on the 9-point hedonic scale. Attiéké of variety Bonoua obtained the smallest hedonic note (5.30). The attiéké of the improved varieties Olekanga and TMS 4 (2) 1425 received 6.60 and 6.00, respectively, which indicates a rather good level on the hedonic scale. The pairwise comparison of hedonic scores indicated that attiéké of variety Bonoua was different from attiéké of IAC, Olekanga and TMS 4 (2) 1425 (p = $0.0001, p=0.0008$ and $p=0.0409$ ). The attiéké of TMS 4 (2) 1425 was different from IAC ( $p=0.02540)$ but not different from Olekanga $(\mathrm{p}=0.1467)$. Similarly, the latter was not significantly different from IAC $(\mathrm{p}=0.4234)$, (Table 3$)$. 
Table 3. Ranging of means of hedonic notes of 4 attiéké from 4 cassava varieties by native tasters.

\begin{tabular}{ccc}
\hline Variety & Means of hedonic notes & Ranging \\
\hline IAC & 7.00 & $\mathrm{a}$ \\
Olekanga (TME 9) & 6.60 & $\mathrm{ab}$ \\
TMS 4(2)1425 & 6.00 & $\mathrm{~b}$ \\
Bonoua & 5.30 & $\mathrm{c}$ \\
\hline
\end{tabular}

\subsection{Definition of the Descriptors of Quality, Mechanical Evaluation and Reference Products}

The attributes for describing attiéké were identified first. For profiling 15 appropriate important descriptors of appearance, flavor and texture were selected. Table 4 presents the quality attributes and their reference products that were used only for the training sessions. Table 5 shows the attributes chosen, their definition and the mechanism of appreciation.

\subsection{Sensory Evaluation of Attiéké}

The training of the panel for sensory evaluation of attiéké was a very important step that the panelists were able to clearly identify the testing techniques for the different attributes of attiéké quality.

The characters (moist, firm, cohesion between grains, odor, aroma and sweet) were much discussed by the panelists. For aroma and odor attributes, no reference product other than attiéké was found.

The different descriptors considered for sensory measurements were: Yellow color, bright, well-formed grains, grain size, rounded grains, presence of fibers, moist, odor, elastic character, aroma, firm, acid and sweet.

\subsubsection{Panelists' Performance and Repetition Variation}

A variance analysis model (mixed procedure) was used to evaluate data.

There were panelist, repetition, product as well as repetition and product interaction effects at the level of the dependent variables: yellow color, brightness, presence of fibers, grain cohesion, moisture content and elasticity (Table 6). Also three sources of variation were identified: panel, product and repetition.

The panel factor was significant $(\mathrm{p}<0.05)$ for all descriptors tested. The average intensities of panelists for attiéké products were calculated for the different characters tested.

The factor product was very highly significant $(\mathrm{p}<0.001)$ for eight descriptors (yellow, bright, presence of fibers, moist, grain cohesion, elastic, granulous and acid) and highly significant for a single descriptor (aroma). There was a large difference between the four different attiéké studied. However, the factor product was not significant $(p>0.05)$ for well-formed grains, grain size, rounded grains, attiéké odor, firm and sweet.

The repetition factor was not significant $(p>0.05)$ in three cases (well-formed grains, rounded grains and aroma). It was significant $(p<0.05)$ in six cases 
Table 4. Reference Products of quality descriptors for sensorial analysis of attiéké on a scale (10 cm length).

\begin{tabular}{|c|c|c|}
\hline Attributes & Reference & intensity [mm] \\
\hline \multicolumn{3}{|c|}{ With eyes } \\
\hline Yellow color & Tapioca/non cooked Coucous Ferrero & $0 / 100$ \\
\hline Bright (Translucent) & Perles de Panzani/Placali & $0 / 100$ \\
\hline Well-formed grains & Attoukpou/non cooked Perles de Panzani & $0 / 100$ \\
\hline Size of grains & $\begin{array}{l}\text { Wheat semolina middle grains/non } \\
\text { cooked Perles de Panzani }\end{array}$ & $0 / 100$ \\
\hline Rounded grains & crushed wheat grains/egg of fish mâchoiron & $0 / 100$ \\
\hline $\begin{array}{c}\text { Fibrous } \\
\text { (Presence of fibers) }\end{array}$ & Gari & 100 \\
\hline Moist & non cooked Ferrero couscous/wet gari (Water) & $0 / 100$ \\
\hline \multicolumn{3}{|c|}{ With nose } \\
\hline Odor of attiéké & Freshly cooked attiéké/attiéké aged at least one week & $100 / 0$ \\
\hline \multicolumn{3}{|c|}{ With fingers } \\
\hline Elastic & Vegetable Sponge & 100 \\
\hline $\begin{array}{l}\text { Cohesion between } \\
\text { grains }\end{array}$ & Cooked Couscous ferrero/Attoukpou & $0 / 100$ \\
\hline \multicolumn{3}{|c|}{ In the mouth } \\
\hline Aroma of attiéké & Freshly cooked attiéké/attiéké aged at least one week & $100 / 0$ \\
\hline Firm & $\begin{array}{l}\text { Well cooked Ferrero Couscous/non cooked } \\
\text { Ferrero Couscous }\end{array}$ & $0 / 100$ \\
\hline Granulous & Garba/Attiéké Agbodjama & $0 / 100$ \\
\hline \multicolumn{3}{|c|}{ The Savor } \\
\hline Acid & Acid Garba & 100 \\
\hline Sweet & Boiled cassava Bonoua & 100 \\
\hline
\end{tabular}

(grain size, odor, cohesion between grains, elastic, firm, and sweet), highly significant $(\mathrm{p}<0.01)$ for moist and acid and very highly significant $(\mathrm{p}<0.001)$ for yellow, bright, presence of fibers and granular characters. There was a large difference between at least two attiéké of the four cassava varieties studied.

\subsubsection{Sensory Profile of Attiéké Studied}

The interpretation of the effects of products (attiéké/variety), repetition and interaction (produced ${ }^{*}$ repetition) included each quality descriptor. This allowed the establishment of the sensory profiling of the studied attiéké from the general averages of each quality descriptor (Figure 5 and Figure 6):

\section{1) Yellow color descriptor}

The attiéké of TMS 4 (2) 1425 and Olékanga were more yellow than of the two other varieties. However, attiéké of variety IAC was more yellow than of Bonoua. The averages of 3 repetitions $(53.70 ; 45.88 ; 56.12)$ showed that attiéké of repetitions 1 and 3 were more yellow than that of repetition 2. The yellow color of 
Table 5. Quality attributes, definition and mechanism of appreciation for sensory evaluation of attieké.

\begin{tabular}{|c|c|c|c|}
\hline Quality attribute & Definition & Mode of testing (English) & Mode de tester (French) \\
\hline & & With eyes & Avec les yeux \\
\hline Yellow & Yellow color & & \\
\hline $\begin{array}{c}\text { Bright } \\
\text { (Translucent) }\end{array}$ & That is bright or shiny & & \\
\hline $\begin{array}{l}\text { Well-formed } \\
\text { grains }\end{array}$ & $\begin{array}{l}\text { Which has well-modelled or } \\
\text { manufactured grains, clearly visible }\end{array}$ & & \\
\hline Size of grains & Showing a size from small to big & & \\
\hline Rounded grains & Which has a round form & & \\
\hline Fibrous & Presence of fibers. & & \\
\hline \multirow[t]{2}{*}{ Moist } & $\begin{array}{c}\text { Which has the appearance of a paste, } \\
\text { that contains balls and too much } \\
\text { water }\end{array}$ & & \\
\hline & & With nose & Avec le nez \\
\hline \multirow[t]{2}{*}{ Odor of attiéké } & $\begin{array}{c}\text { Which has a characteristic } \\
\text { (fermented) odor proper to attiéké } \\
\text { that allows to distinguish it from } \\
\text { others foods }\end{array}$ & & \\
\hline & & With fingers & Avec les doigts \\
\hline Elastic & $\begin{array}{l}\text { Which takes its initial form after } \\
\text { force of pressure }\end{array}$ & $\begin{array}{l}\text { Make a ball of attiéké in the palm with } \\
\text { the hand, squeeze the ball once and } \\
\text { release, see how the attiéké } \\
\text { returns to its original form. }\end{array}$ & $\begin{array}{l}\text { Faire une boule d'attiéké dans la } \\
\text { paume avec la main, presser la } \\
\text { boule une fois et relâcher, voir } \\
\text { comment l'attiéké reprend sa } \\
\text { forme initiale. }\end{array}$ \\
\hline \multirow[t]{2}{*}{$\begin{array}{c}\text { Cohesion between } \\
\text { grains }\end{array}$} & $\begin{array}{l}\text { Which shows a cohesion between } \\
\text { granules or granules pressed against } \\
\text { each other }\end{array}$ & $\begin{array}{c}\text { Press the attiéké with your fingertips and } \\
\text { judge how the grains stick together by } \\
\text { releasing the fingers. }\end{array}$ & $\begin{array}{c}\text { Presser l'attiéké avec le bout des } \\
\text { doigts et juger comment les grains } \\
\text { se collent entre eux en relâchant } \\
\text { les doigts. }\end{array}$ \\
\hline & & In the mouth & Dans la bouche \\
\hline Aroma of attiéké & $\begin{array}{c}\text { Which has a characteristic aroma of } \\
\text { attiéké }\end{array}$ & $\begin{array}{l}\text { Chew a ball of at least } 25 \mathrm{~g} \text { and } \\
\text { appreciate the intensity of the flavor. }\end{array}$ & $\begin{array}{l}\text { Mâcher une boule d'au moins } 25 \mathrm{~g} \\
\text { et apprécier l'intensité de l'arôme. }\end{array}$ \\
\hline Firm & $\begin{array}{l}\text { Which shows high resistance to } \\
\text { distortion }\end{array}$ & $\begin{array}{l}\text { Press the attiéké with the teeth } \\
\text { (preferably on the first stroke of the } \\
\text { chew) and judge whether the } \\
\text { food is soft or firm. }\end{array}$ & $\begin{array}{l}\text { Presser l'attiéké avec les dents (de } \\
\text { préférence au premier coup de } \\
\text { mâche) et constater si l'aliment } \\
\text { est mou ou ferme. }\end{array}$ \\
\hline \multirow[t]{2}{*}{ Granulous } & $\begin{array}{l}\text { Sensation of grains in the mouth } \\
\text { when eating attiéké }\end{array}$ & Feel the grains by eating the attiéké. & $\begin{array}{l}\text { Sentir les grains en mangeant } \\
\text { l'attiéké. }\end{array}$ \\
\hline & & Savor & Arôme \\
\hline Acid & Sensation of acidity & & \\
\hline Sweet & Sensation of sweetness & & \\
\hline
\end{tabular}

attiéké from the improved varieties TMS 4 (2) 1425 and Olekanga was more stable regardless of repetitions, while variety IAC was less yellow at repetition 1. Attiéké of Bonoua was almost white in repetitions 2 (average = 13.41), 3 (57.41) and 4 (55.66). 
Table 6. Analyse of variance of sensory attributes of four attiéké.

\begin{tabular}{|c|c|c|c|c|c|}
\hline \multirow{2}{*}{ Attribut } & \multicolumn{2}{|c|}{ Variance ( $P$ value) } & \multicolumn{3}{|c|}{$P$ value } \\
\hline & Panel & Residual & Product & Repetition & Product ${ }^{*} \operatorname{Rep}$ \\
\hline Yellow color & $120.15(0.0154)$ & $123.93(0.0001)$ & 0.0001 & 0.0001 & 0.0001 \\
\hline Bright & $169.92(0.0132)$ & $114.65(0.0001)$ & 0.0001 & 0.0001 & 0.0001 \\
\hline Well-formed grains & $76.05(0.0156)$ & $80.45(0.0001)$ & 0.7161 & 0.1092 & 0.1048 \\
\hline Size of grains & $119.61(0.0125)$ & $66.54(0.0001)$ & 0.9021 & 0.0413 & 0.2226 \\
\hline Rounded grains & $313.40(0.0108)$ & $76.93(0.0001)$ & 0.4802 & 0.5549 & 0.0089 \\
\hline Fibrous (Presence of fibers) & $193.44(0.0119)$ & $86.63(0.0001)$ & 0.0001 & 0.0004 & 0.0001 \\
\hline Moist & $170.44(0.0127)$ & $101.58(0.0001)$ & 0.0039 & 0.0350 & 0.0123 \\
\hline Odor of attiéké (fermented odor) & $162.66(0.0133)$ & $111.26(0.0001)$ & 0.5480 & 0.0864 & 0.8080 \\
\hline Cohesion between grains & $237.40(0.0112)$ & $76.85(0.0001)$ & 0.0001 & 0.0182 & 0.0003 \\
\hline Elastic & $152.29(0.0119)$ & $68.50(0.0001)$ & 0.0001 & 0.0137 & 0.0511 \\
\hline Aroma of attiéké & $226.68(0.0134)$ & $122.28(0.0001)$ & 0.0141 & 0.0641 & 0.8283 \\
\hline Firm & $269.00(0.0116)$ & $107.64(0.0001)$ & 0.0557 & 0.0184 & 0.0117 \\
\hline Granulous & $185.99(0.0113)$ & $63.37(0.0001)$ & 0.0001 & 0.0009 & 0.9279 \\
\hline Acid & $341.37(0.0119)$ & $154.61(0.0001)$ & 0.0012 & 0.0078 & 0.1688 \\
\hline Sweet & $242.34(0.0120)$ & $114.79(0.0001)$ & 0.6312 & 0.0305 & 0.1592 \\
\hline
\end{tabular}

Variance and $\mathrm{P}$ value are known for panel factor (13 panelists) and residual error. F value for two others factors: product and repetition (four products and three repetitions). Rep = Repetition.

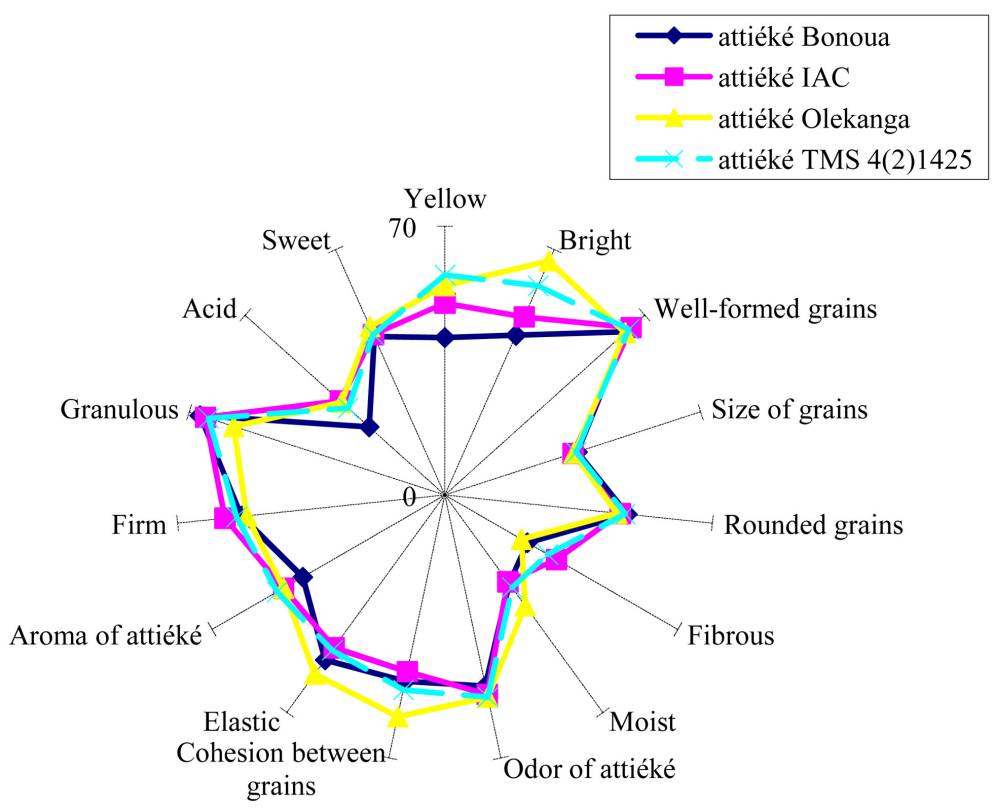

Figure 5. Sensory profile of 4 attiéké from 4 cassava varieties for three repetitions. At the origin, intensity $=0$, at the periphery, intensity $=70$.

\section{2) Brightness descriptor}

Attiéké of variety Olékanga was brighter (68.35) than of TMS 4 (2) 1425 


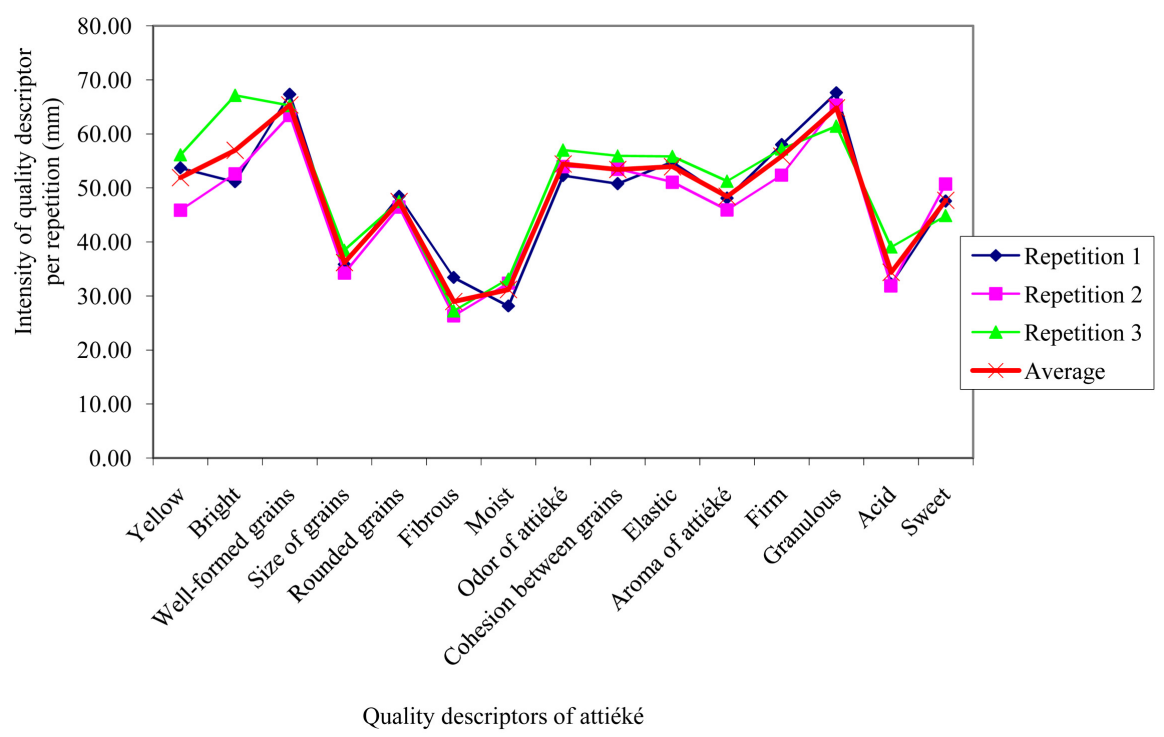

Figure 6. 3 Profile of three repetitions of quality attributes of 4 attiéké of 4 varieties of cassava.

(61.40) and even more brilliant than attiéké of IAC (51.81). Attiéké of variety Bonoua has remained the least brilliant (46.32). The attiéké tested at repetition 3 (67.14) was brighter than those of repetitions 1 (51.12) and 2 (52.63).

3) Well-formed grains descriptor

There was no significant difference between the different varieties $(\mathrm{p}=$ $0.7161)$ and between the 3 replicates $(p=0.1092)$ for the descriptor well-formed grains. The grains of all attiéké produced were well visible and well-built. The four attiéké from IAC, Bonoua, Olekanga, TMS 4 (2) 1425 obtained means of $66.49 ; 65.07 ; 64.11$ and 65.70 .

\section{4) Grain size descriptor}

The difference between attiéké of local and improved cassava was not significant for the grain size character $(\mathrm{p}=0.9021)$. The comparison of repetitions showed that at least one repetition was different from the two others $(\mathrm{p}=$ 0.0413). However, the same size was noted within repetitions for all varieties. The repetition 3 (38.45) had a larger grain size than repetitions 1 (35.73) and 2 (34.23).

\section{5) Grain shape descriptor}

There was a significant difference between the four attiéké for the interaction effect between product and repetition concerning grain shape. At repetition 1, the grains of attiéké obtained from variety Bonoua (53.17) were more rounded than those of TMS 4 (2) 1425 (52.50), Olékanga (46.33) and IAC (41.75). In general, variety Bonoua led to more rounded grains compared to the other varieties in all three repetitions. However, there was no variety $(p=0.4802)$ and repetition effect $(\mathrm{p}=0.5549)$.

6) Presence of fibers descriptor

There was a significant difference in the presence of fibers between attiéké $(\mathrm{p}=0.0001)$ from the different repetitions $(\mathrm{p}=0.0004)$ and there was a product 
interaction effect ${ }^{*}$ repetition $(\mathrm{p}=0.0001)$. Considering means of the three replicates, attiéké of IAC contained more fibers (34.90) than TMS 4 (2) 1425, Bonoua and Olekanga varieties (31.93, 25.37 and 23.73). The fibers content in these finished products of the four attiéké was low compared to the average. In repetition 1, attiéké of IAC had a higher fiber content (53.25) than of all other varieties independent of the repetition. Moreover, the fiber content in attiéké of the other varieties studied remained constant independent of the repetition. The attiéké of the local variety IAC had only few fibers at the level of repetitions 2 (26.16) and 3 (25.29).

\section{7) Moist descriptor}

The difference in moisture content between attiéké of Bonoua, Olekanga, TMS 4 (2) 1425 and IAC varieties was highly significant $(\mathrm{p}=0.0039)$. There was also a significant repetition $(\mathrm{p}=0.0350)$ and interaction effect $(\mathrm{p}=0.0123)$. Attiéké of IAC, Bonoua and TMS 4 (2) 1425 (28.68, 29.18 and 30.44) were relatively dry compared to attiéké of Olékanga (35.55).

8) Odor descriptor

There was no significant difference in odor of attiéké of Bonoua, Olekanga, TMS 4 (2) 1425 and IAC varieties $(\mathrm{p}=0.5480)$. There was no interaction effect between products and repetitions $(\mathrm{p}=0.8080)$. However, there was a low repetition effect $(p=0.0864)$ due to significant differences $(p=0.0293)$ between repetitions 1 and 3 .

\section{9) Cohesion between grains descriptor}

Attiéké of variety Olékanga showed a stronger cohesion between grains (60.78) than of Bonoua, IAC and TMS 4 (2) 1425 varieties (51.10; 53.40) with a high significance $(\mathrm{p}=0.0001)$. Attiéké of IAC exhibited the weakest cohesion between grains. Concerning repetitions, there was a significant difference between repetitions 1 and $3(\mathrm{p}=0.0043)$. Moreover, cohesion between grains of all four attiéké increased with repetition, except in attiéké of variety Bonoua for which cohesion between grains evolved in the opposite direction.

10) Elastic descriptor

The comparison of the four attiéké showed no significant difference for elasticity between Bonoua, IAC and TMS 4 (2) 1425 (respectively 54.60, 50.51, 51.42). However, attiéké of variety Olekanga showed higher elasticity (59.15) than attiéké of the three other cassava varieties. At the level of repetitions, the elasticity mean of repetition 1 (54.83) was not different from repetition 3 (55.85) with $\mathrm{p}=0.5468$.

\section{1) Aroma descriptor}

There was a significant difference $(\mathrm{p}=0.0141)$ between aroma in attiéké of the cassava varieties studied. Attieké of Bonoua had a less intense aroma (43.36) than attiéké of IAC, Olekanga and TMS 4 (2) 1425 (49.44, 49.32, 51.58). For the four attiéké, the intensity of aroma did not vary considerably among repetitions.

12) Firm descriptor

The comparison of the four attiéké showed that there was a significant differ- 
ence between attiéké of IAC and Olekanga varieties with respect to firmness ( $\mathrm{p}=$ 0.0088). Attiéké of variety IAC was firmer (59.47) than attiéké of the improved variety Olekanga (52.96). Attiéké of Bonoua and TMS 4 (2) 1425 was not significantly less firm (54.64 and 56.42, respectively) than attieké of IAC. In contrast, the difference between the 3 repetitions was significant $(p=0.0184)$, but repetitions 1 and 3 were not different from each other $(\mathrm{p}=0.7165)$.

13) Granulous descriptor

The difference between means of granulousity of the four attiéké was highly significant $(\mathrm{p}=0.0001)$. Similarly, the difference in repetitions was significant $(\mathrm{p}<$ 0.001 ). The comparison of averages revealed that attiéké of variety Olekanga (58.72) was significantly less granulous $(\mathrm{p}<0.0001)$ than attiéké of Bonoua, IAC and TMS 4 (2) 1425 (68.21, 66.57, 65.68 respectively). Repetition 3 (61.42) was significantly different $(\mathrm{p}=0.01)$ from repetitions 1 (67.63) and $2(65.34)$. The attiéké produced at repetition 3 possessed the least pronounced granular character.

\section{4) Acid descriptor}

The comparison of the acid character of attiéké showed that only attiéké of variety Bonoua was significantly different from the attiéké of the three other varieties. The local variety Bonoua resulted in the least acid attiéké (27.31) compared to attiéké of IAC, Olekanga and TMS 4 (2) 1425 (37.88, 37.58 and 34.79, respectively). When considering means of the three repetitions $(32.32,31.90$ and 39.04, respectively), repetition 3 was significantly different from repetitions 1 and 2.

\section{5) Sweet descriptor}

There was no significant difference in sweetness between attiéké derived from the four cassava varieties $(\mathrm{p}=0.6312)$. On the whole, the sweet descriptor was not a criterion for differentiating attiéké. Attiéké of all varieties were close to the average of the sensory scale. Between the three repetitions (47.54, 50.72 and 44.86 , respectively), only repetition 3 was significantly different from repetition $2(\mathrm{p}=0.0085)$.

\subsubsection{Correlations between Sensory Attributes}

Pearson correlation coefficients (Table 7 ) revealed that the descriptor yellow color of attiéké was significantly correlated with descriptors bright $(\mathrm{p}<0.0001, \mathrm{r}=$ 0.91), aroma ( $\mathrm{p}<0.01, \mathrm{r}=0.72)$, well-formed grains $(\mathrm{p}<0.05, \mathrm{r}=0.56)$ and rounded grains $(\mathrm{p}<0.05, \mathrm{r}=0.57)$. Brightness was significantly positive correlated with the descriptors odor $(\mathrm{p}<0.05, \mathrm{r}=0.61)$, aroma intensity $(\mathrm{p}<0.05, \mathrm{r}=$ $0.61)$ and inversely correlated with the descriptor granulous $(\mathrm{p}<0.05, \mathrm{r}=$ -0.59 ). The descriptor well-formed grains was significantly positive correlated with the descriptor rounded grains $(\mathrm{p}<0.01, \mathrm{r}=0.70)$ and inversely correlated with the moisture content $(\mathrm{p}<0.01, \mathrm{r}=-0.68)$. The presence of fibers was significantly negative correlated with grain cohesion $(\mathrm{p}<0.05, \mathrm{r}=-0.59)$ and positive correlated with firmness $(\mathrm{p}<0.001, \mathrm{r}=0.85)$. The moisture content was significantly positive correlated with the descriptors odor $(\mathrm{p}<0.05, \mathrm{r}=0.58)$, cohesion 
Table 7. Correlation between measured different sensory descriptors of attiéké.

\begin{tabular}{|c|c|c|c|c|c|c|c|c|c|c|c|c|c|c|c|}
\hline Variables & Yellow & Bright & $\begin{array}{c}\text { Well-for } \\
\text { med } \\
\text { grain }\end{array}$ & $\begin{array}{c}\text { Size } \\
\text { of grains }\end{array}$ & $\begin{array}{c}\text { Rounded } \\
\text { grains }\end{array}$ & Fibrous & Moist & $\begin{array}{l}\text { Odor } \\
\text { of } \\
\text { attiéké }\end{array}$ & $\begin{array}{c}\text { Cohesion } \\
\text { between } \\
\text { grains }\end{array}$ & Elastic & $\begin{array}{l}\text { Aroma } \\
\text { of } \\
\text { attiéké }\end{array}$ & Firm & Granulous & Acid & Sweet \\
\hline Yellow & 1 & & & & & & & & & & & & & & \\
\hline Bright & 0.91 & 1 & & & & & & & & & & & & & \\
\hline $\begin{array}{l}\text { Well-forme } \\
\text { d grains }\end{array}$ & 0.56 & & 1 & & & & & & & & & & & & \\
\hline $\begin{array}{l}\text { Size of } \\
\text { grains }\end{array}$ & & & & 1 & & & & & & & & & & & \\
\hline $\begin{array}{l}\text { Rounded } \\
\text { grains }\end{array}$ & 0.57 & & 0.70 & & 1 & & & & & & & & & & \\
\hline Fibrous & & & & & & 1 & & & & & & & & & \\
\hline Moist & & & -0.68 & & & & 1 & & & & & & & & \\
\hline $\begin{array}{l}\text { Odor of } \\
\text { attiéké }\end{array}$ & & 0.61 & & & & & & 1 & & & & & & & \\
\hline $\begin{array}{c}\text { Cohesion } \\
\text { between } \\
\text { grains }\end{array}$ & & & & & & -0.59 & 0.82 & & 1 & & & & & & \\
\hline Elastic & & & & 0.58 & & & 0.59 & & 0.75 & 1 & & & & & \\
\hline $\begin{array}{l}\text { Aroma of } \\
\text { attiéké }\end{array}$ & 0.72 & 0.61 & & & & & & 0.71 & & & 1 & & & & \\
\hline Firm & & & & & & 0.85 & & & & & & 1 & & & \\
\hline Granulous & & -0.59 & & & & & -0.64 & -0.59 & -0.74 & & & & 1 & & \\
\hline Acid & & & & & & & & 0.54 & & & 0.78 & & -0.63 & 1 & \\
\hline Sweet & & & & & & & 0.51 & & & & & & & & 1 \\
\hline
\end{tabular}

Pearson Correlation Coefficients, Prob $>|\mathrm{r}|$ under H0: Rho $=0$.

between grains $(\mathrm{p}<0.001, \mathrm{r}=0.82)$, elastic $(\mathrm{p}<0.05, \mathrm{r}=0.59)$ and sweet $(\mathrm{p}<0.05$, $r=0.51)$. The odor of attiéké was significantly positive correlated with the descriptors aroma intensity $(\mathrm{p}<0.01, \mathrm{r}=0.71)$, acid $(\mathrm{p}<0.05, \mathrm{r}=0.54)$ and negatively with the descriptor granulous ( $\mathrm{p}<0.05, \mathrm{r}=-0.59)$. The cohesion between grains was significantly positive correlated with elasticity $(\mathrm{p}<0.001, \mathrm{r}=0.75)$ and negatively with granulousity $(\mathrm{p}<0.001, \mathrm{r}=-0.74)$. Aroma intensity was positively correlated with the descriptor acid $(\mathrm{p}<0.001, \mathrm{r}=0.78)$. The latter was inversely correlated with the descriptor granulous $(\mathrm{p}<0.05, \mathrm{r}=-0.63)$.

\subsubsection{Correlations between Sensory Attributes and the Four Attiéké Studied}

The principal component analysis of the sensorial profile of the four attiéke is shown in Figures 7 (a)-(c). The table of eigenvalues explained variances resulting from this analysis, indicating that two main components were sufficient to represent more than $92 \%$ (cumulative percentage) of the initial inertia (of searched information). The axes 1 and 2 explain 92\% of information resulting 

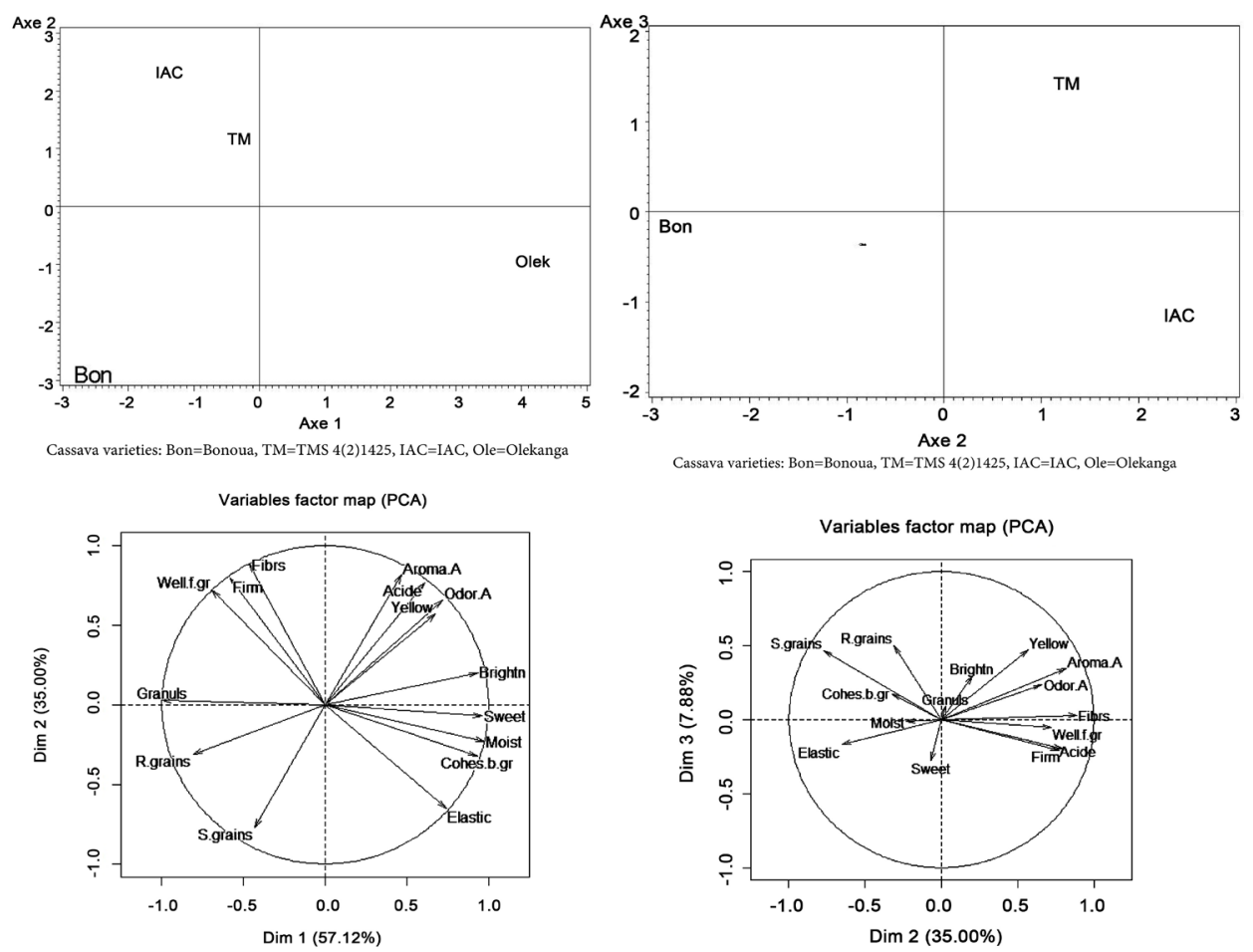

(a)

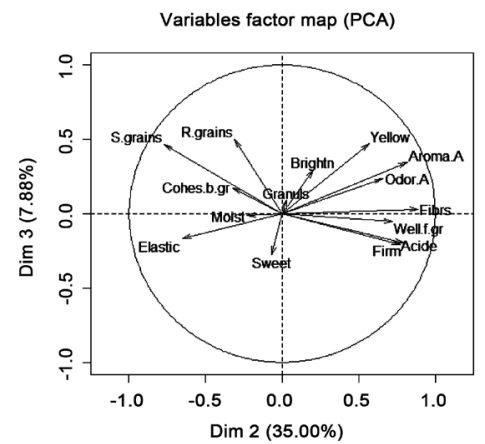

(b)

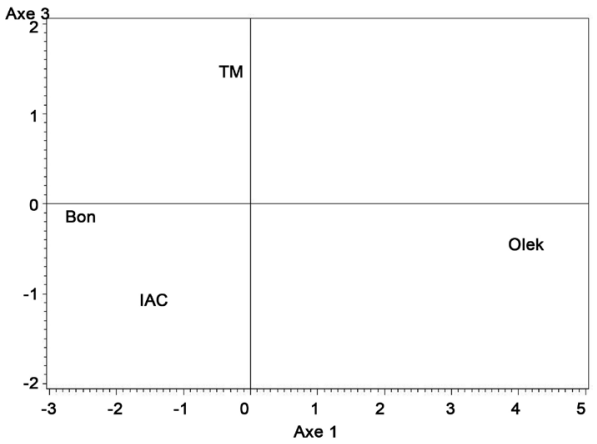

Cassava varieties: Bon=Bonoua, TM=TMS 4(2) 1425, IAC=IAC, Ole=Olekanga

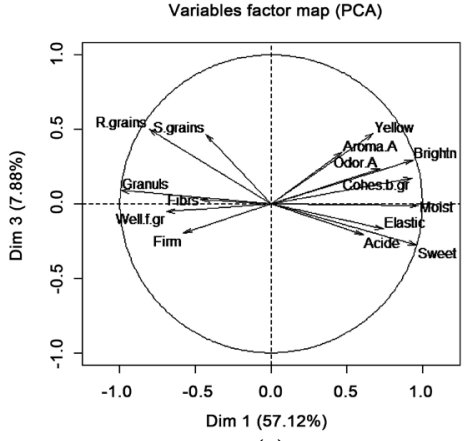

(c)

Figure 7. (a) PCA on the descriptors of attiéké quality and the 4 cassava varieties used for manufacturing attiéké. Graph of individuals and correlation circle of axes 1 and 2; (b) PCA on the descriptors of attiéké quality and the 4 cassava varieties used for manufacturing attiéké. Graph of individuals and correlation circle of axes 2 and 3; (c) PCA on the descriptors of attiéké quality and the 4 cassava varieties used for manufacturing attiéké. Graph of individuals and correlation circle of axes 1 and 3 . Yellow = Yellow color, Brightn = Bright, Well-f.gr $=$ Well-formed grains, S. grains $=$ Size of grains, R. grains = Rounded grains, Fibrs $=$ Presence of fibers or fibrous, Moist $=$ Moist, Odor. A = Odor of attiéké, Elastic = Elastic, Cohes.b.gr = Cohesion between grains, Aroma. $\mathrm{A}=$ Aroma of attiéké, Firm = Firm, Granuls $=$ Granulous, Acide $=$ Acid, Sweet $=$ Sweet. 
from the representation of coordinates of individuals with respect to the axes. The first main component accounts for $57 \%$ and the second for $35 \%$ of information. This means that the attributes tested have been reduced to two dimensions and $92 \%$ of total information can be explained by the graphs obtained. The axis 1 of correlation circle contrasted brightness, sweetness, grain cohesion and moisture with the attributes granular and rounded grains (Figure 7(a)). The axis 1 of graph (Figure 7(a)) highlighted an opposition between attiéké of the improved variety Olekanga and those of local varieties Bonoua and IAC. Attiéké of variety Olekanga (cont1: 50.33) strongly contributes to axis 1.

Finally attiéké of Olekanga was brighter, sweeter, had a stronger cohesion of grains and was moister than attiéké of varieties Bonoua and IAC. Attiéké of these two varieties were more granulous and had more rounded grains. The axis 2 of correlation circle contrasted the attributes well-formed, fibrous, firm, acid and odor of attiéké with grain size (Figure 7(b)).

The axis 2 of graph (Figure 7(b)) contrasted attiéké of local variety Bonoua with those of IAC and TMS 4 (2) 1425. The two attiéké of Bonoua (Cont2: 37.24) and IAC (Cont2: 27.10) strongly contributed to axis 2 . The third main component was mainly linked to the quality descriptors yellow, grain size and rounded grains.

Attiéké of the improved variety TMS 4 (2) 1425 strongly contributed to axis 3 and was strongly associated with the descriptors: yellow, grain size and rounded grains (Figure $7(\mathrm{c})$ ).

\subsubsection{Correlations between Sensory Attributes and Biochemical Characteristics of Attiéké}

Pearson correlation coefficients (Table 8) showed that $\mathrm{pH}$ of attiéké was significantly positive correlated with grain size $(\mathrm{r}=0.99, \mathrm{p}<0.0001)$ and inversely correlated with acidity perceived by the sensory panel $(r=-0.92, p \leq 0.05)$. The acid taste of attiéké was significantly inverse correlated with grain size $(r=$ $-0.93, \mathrm{p}<0.05)$ and rounded grains $(\mathrm{r}=-0.98, \mathrm{p}<0.05)$.

The starch content of the cassava tuber was significantly positive correlated with a granular structure $(\mathrm{r}=0.97, \mathrm{p}<0.05)$ and inversely with brightness $(\mathrm{r}=$ $-0.96, \mathrm{p}<0.05)$, moisture $(\mathrm{r}=0.97, \mathrm{p}<0.05)$, grain cohesion $(\mathrm{r}=0.96, \mathrm{p}<0.05)$ and sweetness $(\mathrm{r}=0.95, \mathrm{p} \leq 0.05)$ of prepared attiéké. The total amount of sugars of attieké was significantly positive correlated with yellow $(r=0.96, p<0.05)$ and aroma intensity $(\mathrm{r}=0.96, \mathrm{p}<0.05)$ whereas the reducing sugars of attieké were significantly positive correlated with the color yellow $(r=0.99, \mathrm{p}<0.01)$, odor $(\mathrm{r}=0.95, \mathrm{p}<0.05)$ and aroma intensity $(\mathrm{r}=0.96, \mathrm{p}<0.05)$. The cyanide content was significantly correlated with presence of fibers $(r=0.95, p \leq 0.05)$.

The total amount of sugars of attieké was significantly positive correlated with yellow $(\mathrm{r}=0.96, \mathrm{p}<0.05)$ and aroma intensity $(\mathrm{r}=0.96, \mathrm{p}<0.05)$ whereas the reducing sugars of attieké were significantly positive correlated with the color yellow $(\mathrm{r}=0.99, \mathrm{p}<0.01)$, odor $(\mathrm{r}=0.95, \mathrm{p}<0.05)$ and aroma intensity $(\mathrm{r}=$ $0.96, \mathrm{p}<0.05)$. The cyanide content was significantly correlated with presence of 
Table 8. Correlation between physicochemical characteristics and sensory attributes of attiéké.

\begin{tabular}{|c|c|c|c|c|c|c|}
\hline \multirow[b]{2}{*}{ Sensory attributes } & \multicolumn{6}{|c|}{ Physicochemical parameters } \\
\hline & $\mathrm{pH}$ & Titrable acidity & Starch & Total sugars & Reducing sugars & Cyanide $(\mathrm{HCN})$ \\
\hline \multirow{2}{*}{ Yellow color } & & & & $\mathrm{r}=0.96$ & $r=0.99$ & \\
\hline & & & & $\mathrm{p}<0.05$ & $\mathrm{p}<0.01$ & \\
\hline \multirow{2}{*}{ Bright (Translucent) } & & & $\mathrm{r}=-0.96$ & & & \\
\hline & & & $\mathrm{p}<0.05$ & & & \\
\hline \multirow{2}{*}{ Size of grains } & $\mathrm{r}=0.99$ & $r=-0.93$ & & & & \\
\hline & $\mathrm{p}<0.0001$ & $\mathrm{p}<0.05$ & & & & \\
\hline \multirow{2}{*}{ Rounded grains } & & $\mathrm{r}=-0.98$ & & & & \\
\hline & & $\mathrm{p}<0.05$ & & & & \\
\hline \multirow{2}{*}{ Fibrous } & & & & & & $r=0.95$ \\
\hline & & & & & & $\mathrm{P} \leq 0.05$ \\
\hline \multirow{2}{*}{ Moist } & & & $\mathrm{r}=-0.97$ & & & \\
\hline & & & $\mathrm{p}<0.05$ & & & \\
\hline \multirow{2}{*}{ Odor of attiéké } & & & & & $\mathrm{r}=0.95$ & \\
\hline & & & & & $\mathrm{P}<0.05$ & \\
\hline Cohesion between & & & $r=-0.96$ & & & \\
\hline grains & & & $\mathrm{P}<0.05$ & & & \\
\hline \multirow{2}{*}{ Aroma of attiéké } & & & & $r=0.96$ & $r=0.96$ & \\
\hline & & & & $\mathrm{P}<0.05$ & $\mathrm{P}<0.05$ & \\
\hline \multirow{2}{*}{ Granulous } & & & $\mathrm{r}=0.97$ & & & \\
\hline & & & $\mathrm{P}<0.05$ & & & \\
\hline \multirow{2}{*}{ Acid } & $r=-0.92$ & & & & & \\
\hline & $\mathrm{P} \leq 0.05$ & & & & & \\
\hline \multirow{2}{*}{ Sweet } & & & $\mathrm{r}=-0.95$ & & & \\
\hline & & & $\mathrm{P} \leq 0.05$ & & & \\
\hline
\end{tabular}

Pearson Correlation Coefficients, Prob $>|r|$ under H0: Rho $=0$. NB: This table showed the sensory attributes that are correlated with physicochemical variables of attiéké.

fibers $(\mathrm{r}=0.95, \mathrm{p} \leq 0.05)$.

\section{Discussion}

\subsection{Relationship between Quality and Choice of Attiéké}

Pearson correlation coefficients between attributes studied revealed that the yellow character may indicate brightness of attiéké at the level of appearance. The attribute well-formed grains may well account for characters rounded grains and moist. The attribute acid may be linked to odor and aroma intensity. Sweet may be positively related to the flavor of attiéké. The cohesion character between grains may account for the attributes elastic and moist.

Firmness may be influenced by the presence of fibers. The four attributes: grain size, granular character, firmness and cohesion between grains were the most relevant textural characteristics for attiéké. Based on Pearson correlations the 15 descriptors could be reduced to 9 determinants for the organoleptic qual- 
ity of attiéké for future analyses. These were the attributes yellow, well-formed grains, acid, odor, sweet, firm, size of grains, granulous and cohesion of grains. However, odor and aroma intensity of attiéké were highly correlated with the acid character.

The odorous components were not identified but may be lactic acid, aldehyde, ethanol, and acetic acid produced during fermentation of the pulp of cassava roots. In addition to its fundamental role in acidulated savor, acid has a great influence on the sensory perception of volatile components of food. These volatile compounds are the main components of the typical aroma and aftertaste of a food [22]. Non-volatile compounds such as sugars, acids, and minerals are responsible for acidulated, sweet, slightly bitter and salty savors of attiéké. The sweetness of attiéké was not correlated with any other attributes. The sweet taste may be correlated with non-volatile chemicals such as total sugars or starch content. The correlation of well-formed grains with rounded grains may easily be determined by the skills of producers. The term well-formed grain refers to the expertise of the producers [23].

The importance of descriptors (size of grains and granules) is determinant for texture. The cohesion between grains remains an important attribute for both producers and consumers [23]. This attribute refers to the strength of bonds between attiéké grains containing gelled and viscous starch during steam cooking [24] and might be important for a desired moisture content and elasticity of attiéké. The heat treatment of starch in a moist environment results in gelatinization. At nutritional level, gelatinization of starch makes it digestible. The gelatinization of starch during the steam cooking of attiéké is also responsible for its brightness [24] [25], and therefore its brilliance. This brings out the color of attiéké, which is often referred to creamy or bright yellow.

\subsection{Relationship between Hedonic and Organoleptic Qualities of the Attiéké}

The sensory properties may strongly contribute to the difference in appreciation by naive tasters of the four attiéké.

The sensory profiles of the studied cassava attiéke revealed that the main differences at the level of quality concern the nine attributes yellow, bright, fibrous, cohesion between grains, elastic, moist, granulous, acid and intensity of aroma.

Attiéké of IAC, the most appreciated cassava variety by naive tasters, exhibited higher scores in acid, granulous, aroma intense, firm and fibrous characters compared to attiéké of the other varieties. One could interpret that consumers are sensitive to these quality parameters. So, with regard to the quality of attiéké Ebrié, it is important the savor being acidulated with a characteristic aroma of attiéké, a granulous and firm texture. Referring to attiéké of variety Olekanga, the quality criteria bright, sweet, cohesion between grains, elastic and moist were important for consumers.

The brightness was highly correlated with yellow and was important for con- 
sumers of attiéké. The results showed that while attiéké from variety IAC was the most fibrous, it contained few fibers relatively to the average of evaluation. The cohesion between grains was high for attiéké of variety Olekanga and proportional to its moisture content.

According to the references [26] and [27], the desired viscosity and texture of starches are obtained after cooking in water. The starch granules absorb water corresponding to about $40 \%$ to $50 \%$ of their weight. However, attiéké starch of the improved variety Olekanga tends to absorb more water than starch of the other examined cassava varieties.

Furthermore, the solubility and viscosity of starch seems to be related to toxicity of cassava variety. According to the reference [28], starches of bitter cassava varieties are characterized by high solubility and low viscosity. These physicochemical parameters may explain that the bitter variety IAC exhibited attiéké with higher cohesion between grains, lower elasticity and lower moisture compared to the three other varieties.

At the hedonic level, attiéké of the local variety Bonoua was the least appreciated. The characters yellow and bright were the two attributes that may have disqualified this attiéké. This result is in full agreement with [23] who state that the color plays an important role in assessing the quality of foods.

\subsection{Effect of Cassava Variety and Manufacturing Process on the Organoleptic Quality}

Comparison of each quality descriptor revealed that well-formed, rounded grains, odor, and intensity of aroma were highly dependent on the producer or manufacturing process. During preparation of attiéké, producers may well control whether these aspects are sufficiently stable independent of the repetition. The characters grain size, cohesion between grains, elastic, firm and sweet did not depend on the producer but were linked to the variety of cassava, pressure, nature of starch and fermentation; in other terms they were linked to the manufacturing process.

The references [29] and [30] showed the effect of cultivar and harvest age on organoleptic properties (taste and texture) of boiled cassava roots.

In the present study, characteristics such as odor, aroma intensity and acid taste of attiéké were strongly linked to the manufacturing process, particularly at the stage of heterolactic fermentation of cassava as found by [2].

The reference [31] reported that spontaneous lactic fermentation produces organic acids, and other volatile compounds that give a characteristic odor to foo-foo (a traditional fermented cassava paste). This production of acidity has been attributed to actions of lactic acid bacteria on carbohydrates of cassava and conditions of the manufacturing process of a traditional paste of fermented cassava flour [32] [33]. The reference [34] reported that there is no significant difference between profiles of acid production during fermentation of different cassava varieties studied in this process. Therefore, odor and aroma of attiéké are 
not factors which differentiate the studied varieties of cassava.

\subsection{Relationship between Physicochemical Quality Descriptors}

Pearson correlation coefficients between physicochemical quality descriptors of the four attiéké Ebrié showed that sensory characteristics can be predicted by biochemical parameters. When the $\mathrm{pH}$ decreased, attiéké became more acid and the grain size decreased. The $\mathrm{pH}$ was correlated to the sensory attributes grain size and acid taste of attiéké. Similarly, the acidity rate may well account for size of grains and rounded grains. The acidity rate and $\mathrm{pH}$ are related to the evolution of fermentation in cassava roots and the softening of its structure [35] [36]. A finer semolina may play a role for obtaining large and rounded grains. Therefore, the starch content could account for the descriptors granulousity, brightness, moisture, cohesion between grains and sweetness. This indicates that attiéké containing a high starch content may be more granulous, less moist and have less cohesion between grains as well as a less sweet taste. Cassava of variety Olekanga contained less starch ( $80 \%$ compared to the other varieties used) and attiéké prepared therefrom was less granulous, brighter, moister and with stronger grain cohesion than attiéké of IAC, Bonoua and TMS 4 (2) 1425 (starch content $=94.11 \%, 97.32 \%, 86.70 \%$, respectively) .

The total sugar content and the reducing sugars could account for the intensity of aroma and odor of attiéké. Carbohydrates are well-known flavor carriers and have a great influence on volatile constituents of food [36]. The presence of carbohydrates alters the sensory perception of aromas.

\section{Conclusions}

Sensory profiling of attiéké from four cassava varieties harvested at 12 months revealed a difference between nine determinant descriptors of organoleptic quality based on Pearson correlations. These are: yellow color, acidity, sweetness, odor, firmness, size of grains, well-formed grains, granular character and cohesion of grains. The four attributes, grain size, granular character, firmness and cohesion between grains have been found to be the most relevant textural characteristics for attiéké.

At the hedonic level, attiéké of the local variety Bonoua was the least appreciated. The characters yellow and bright were the two attributes that may have disqualified this attiéké.

Cassava variety and manufacturing process may have an influence on the organoleptic quality of the traditional attiéké Ebrié but do not always affect its quality descriptors.

Some organoleptic characteristics of the analyzed attiéké can be predicted by biochemical properties.

The descriptors selected in the present study could be used for sensory analysis of different types of traditional, improved (standardized) and industrial attiéké produced in Côte d'Ivoire and anywhere else. 


\section{Acknowledgements}

Thanks are due to Laboratory of Biochemistry and Food Science, University Félix Houphouët Boigny (Côte d'Ivoire), Swiss Center of Scientific Research (Côte d'Ivoire), Swiss Federal Institute of Technology (ETH), Zurich (Switzerland) and International Foundation for Sciences (Grant No: E/3509-1) (IFS, Sweden) for technical assistance and financial support. Many thanks to Koné Mamidou Witabouna, Professor (University Nangui Abrogoua) for proofreading this article.

\section{Conflicts of Interest}

The authors declare no conflicts of interest regarding the publication of this paper.

\section{References}

[1] Kouadio, N.A., Kouakou, K.E., Angbo, S.F. and Mosso, K. (1991) Comparative Study of Traditional Methods of Preparing attiÉké in Southern Côte d'Ivoire. Cahier Scientifique et Technique, 108, 703-706.

[2] Assanvo, J.B., Agbo, N.G., Behi, Y.E.N., Coulin, P. and Farah, Z. (2006) Microflora of Traditional Starter Made from Cassava for "Attiéké" Production. Food Control, 17, 37-41. https://doi.org/10.1016/j.foodcont.2004.08.006

[3] Aboua, F., Kossa, A., Konan, K., Mosso, K., Angbo, S. and Kamenan, A. (2006) Analysis of Some Cassava Constituents during the Preparation of attiéKé. In: Foua, B.K. and Philomene, B.J.R., Eds., Postharvest in Africa, International Seminary, Abidjan (Ivory Coast), Vol. 1, 217-221.

[4] Assanvo, J.B. (2008) Evaluation of Traditional Ivorian Attiéké Qualities: Survey on Production and Consumption, Physicochemical, Microbiological and Sensory Characterization of Four Cassava Varieties (IAC, Bonoua, Olekanga and TMS 4 (2) 1425). Ph.D. Thesis, Laboratory of Biochemistry and Food Sciences/UFR Biosciences, University of Cocody, Abidjan, Ivory Coast.

[5] Coulin, P., Farah, Z., Assanvo, J., Spillmann, H. and Puhan, Z. (2006) Characterisation of Microflora of attiéké, a Fermented Cassava Product, during Traditional Small-Scale Preparation. International Journal of Food Microbiology, 106, 131-136. https://doi.org/10.1016/j.ijfoodmicro.2005.06.012

[6] Oyewole, O.B. and Sanni, L.O. (1995) Constraints in Traditional Cassava Processing. In: Agbor-Egbe, T., Brauman, A., Griffon, D. and Treche, S., Eds., Cassava Food Processing, Orstom, Paris, 523-529.

[7] Chuzel, G., Cereda, M. and Griffon, D. (1996) Cassava-Based Fermented Foods. In: Bourgois, C.M. and Larpent, J.P., Coordinators, Food Microbiology, Volume 2, Fermented Foods and Food Fermentations, 2nd Edition, Technical and Documentation, Paris, 251-273.

[8] Fortin, J., Desmarais, G., Assovie, O. and Diallo, M. (1998) Attiéké, Couscous from Côte d'Ivoire. Le Monde alimentaire, 2, 22-24.

[9] FAO (2001) Roots, Tubers, Plantains and Bananas in Human Nutrition. Alimentation Nutrition $\mathrm{N}^{\mathrm{o}}$. 24, FAO, Ed., Rome.

[10] Obilie, E.M., Tano-Debrah, K. and Amoa-Awua, W.K. (2003) Microbial Modification of the Texture of Grated Cassava during Fermentation into Akyeke. International Journal of Food Microbiology, 89, 275-280. 
https://doi.org/10.1016/S0168-1605(03)00294-0

[11] Obilie, E.M., Tanoh-Debrah, K. and Amoa-Awua, W.K. (2004) Souring and Breakdown of Cyanogenic Glucosides during the Processing of Cassava into Akyeke. International Journal of Food Microbiology, 93, 115-121. https://doi.org/10.1016/j.ijfoodmicro.2003.11.006

[12] Heuberger, C. (2005) Cyanide Content of Cassava and Fermented Products with Focus on Attiéké and attiÉké "Garba". Ph.D. Thesis ETH No 16247, Swiss Federal Institute of Technology, Zurcih.

[13] Kastner, S., Tschannen, A., Assanvo, J., Agbo, N.G., Farah, Z., Lacroix, C. and Meile, L. (2007) Microbes in Cassava Fermentation towards the Improvement of attiéké Quality and Safety. Proceedings of International workshop: Potential of Cassava (Manihot esculenta, Crantz) Processing in West Africa, Abidjan, Côte d'Ivoire, 4-7 June 2007, 248-251.

[14] Aboua, F. (1998) Optimum Conditions for Cooking Attiéké. Tropical Science, 38, 220-223.

[15] Behi, N.E.Y., Diallo, S.S., Ayemou S.A., Kouadio, K.K.H., Abega, J., Kouame, P., Ayemou, A., Lehmann, B. and Girardin, O. (2002) Agronomic and Technological Evaluation of Improved Varieties of Cassava in Côte d'Ivoire for Dissemination. Bioterre, Proceedings of the International Symposium, Swiss Center, 27-29 August 2001, Special No. 271-285.

[16] Essia, N.J.-J., Kouebou, C.P. and Djoulde, D.R. (2003) Protein Enrichment of Attiéké (Cassava-Based Semolina): Comparison of Two Protein Sources, Saccharomyces cerevisiae and Voandzeia subterranea (Ground Pea). 2nd International Workshop, Food Ways to Improve Nutritional Situations, Ouagadougou, 23-28 November 2003, 589-598.

[17] Assanvo, J.B., Agbo G.N., Coulin, P., Monsan, V., Heuberger, C., Kati-Coulibaly, S. and Farah, Z. (2017) Influence of Microbiological and Chemical Quality of Traditional Starter Made from Cassava on "Attiéké" Produced from Four Cassava Varieties. Food Control, 78, 286-296. https://doi.org/10.1016/j.foodcont.2017.02.066

[18] Amoa-Awua, W.K.A., Appoh, F.E. and Jakobsen, M. (1996) Lactic Acid Fermentation of Cassava Dough into Agbelima. International Journal of Food Microbiology, 31, 87-98. https://doi.org/10.1016/0168-1605(96)00967-1

[19] Dubois, M., Gilles, K., Hamilton, J.K., Rebers, P.A. and Smith, F. (1956) Colorimetric Method for Determination of Sugars and Related Substances. Analytical Chemistry, 28, 350-356. https://doi.org/10.1021/ac60111a017

[20] Bradbury, M.G., Egan, S.V. and Bradbury, J.H. (1999) Picrate Paper Kits for Determination of Total Cyanogens in Cassava Roots and All Forms of Cyanogens in Cassava Products. Journal of the Science of Food and Agriculture, 79, 593-601. https://doi.org/10.1002/(SICI)1097-0010(19990315)79:4<593::AID-JSFA222>3.0.CO $\underline{; 2-2}$

[21] Stone, H. and Sidel, J.L. (2004) Sensory Evaluation Practices. Food Science and Technology. International Series, 3rd Edition, Elsevier Academic Press, London, $377 \mathrm{p}$.

[22] Chambers IV, E. and Koppel, K. (2013) Associations of Volatile Compounds with Sensory Aroma and Flavor: The Complex Nature of Flavor. Molecules, 18, 4887-4905. https://doi.org/10.3390/molecules 18054887

[23] Nout, R., Hounhouigan, J.D. and Boekel, T.V. (2003) Food, Processing, Conservation and Quality. Backhuys Publishers and CTA, Wageningen, The Netherlands, $268 \mathrm{p}$. 
[24] Chena, P., Yua, L., Simon, G.P., Liua, X., Deanc, K. and Chen, L. (2011) Internal Structures and Phase-Transitions of Starch Granules during Gelatinization. Carbohydrate Polymers, 83, 1975-1983. https://doi.org/10.1016/j.carbpol.2010.11.001

[25] Wang, S.J. and Copeland, L. (2013) Molecular Disassembly of Starch Granules during Gelatinization and Its Effect on Starch Digestibility: A Review. Food Function, 4, 1564-1580. https://doi.org/10.1039/c3fo60258c

[26] Wang, S., Li, C., Copeland, L., Niu, Q. and Wang, S. (2015) Starch Retrogradation: A Comprehensive Review. Comprehensive Reviews in Food Science and Food Safety, 14, 568-585. https://doi.org/10.1111/1541-4337.12143

[27] Padonou, W., Mestres, C. and Nago, C.M. (2005) The Quality of Boiled Cassava Roots: Instrumental Characterization and Relationship with Physicochemical Properties and Sensorial Properties. Food Chemistry, 89, 261-270.

https://doi.org/10.1016/j.foodchem.2004.02.033

[28] Wheatley, C. and Gomez, G. (1985) Evaluation of Some Quality Characteristics in Cassava Storage Roots. Plant Foods for Human Nutrition, 35, 121-129. https://doi.org/10.1007/BF01092127

[29] Asaoka, M., Blanshard, J.M.V. and Richard, J.E. (1991) Seasonal Effects on the Physico-Chemical Properties of Starch from Four Cultivars of Cassava. Starch, 43, 455-459. https://doi.org/10.1002/star.19910431202

[30] Kimaryo, V.M., Massawe, G.A., Olasupo, N.A. and Holzapfel, W.H. (2000) The Use of Starter Culture in the Fermentation of Cassava for Production of "Kivunde", a Traditional Tanzanian Food Product. International Journal of Food Microbiology, 56, 179-190. https://doi.org/10.1016/S0168-1605(00)00159-8

[31] Oyewole, O.B. and Odunfa, S.A. (1990) Characterization and Distribution of Lactic Acid Bacteria in Cassava Fermentation during Fufu Production. Journal of Applied Bacteriology, 68, 145-152. https://doi.org/10.1111/j.1365-2672.1990.tb02559.x

[32] Oyewole, O.B. (1990) Optimization of Cassava Fermentation for Fufu Production: Effect of Single Starter Cultures. Journal of Applied Bacteriology, 68, 49-54. https://doi.org/10.1111/j.1365-2672.1990.tb02547.x

[33] Oyewole, O.B. and Afolami, O.A. (2001) Quality and Preference of Different Cassava Varieties for "Lafun" Production. Journal of Food Technology in Africa, 6, 27-29.

[34] Brauman, A., Keleke, S., Malonga, M., Maimbi, E. and Ampe, F. (1996) Microbiological and Biochemical Characterization of Cassava Retting, a traditional Lactic Acid Fermentation for Foo-Foo (Cassava Flour Production). Applied Environmental Microbiology, 62, 2854-2858.

[35] Ogbo, F.O. (2003) Improvement of Organoleptic Quality of Retted Cassava Products by Alkali Pre-Treatment of Roots and Addition of Sodium Nitrate during Retting. International Journal of Food Microbiology, 89, 85-90. https://doi.org/10.1016/S0168-1605(03)00113-2

[36] Naknean, P. and Meenune, M. (2010) Factors Affecting Retention and Release of Flavour Compounds in Food Carbohydrate. International Food Research Journal, 17, 23-34. 